Fety Vera

Analisis Praktik Pengembangan Usaha Minimarket Berdasarkan Peraturan Walikota Palembang Nomor 25 Tahun 2011 Tentang Pedoman Penataan Dan Pembinaan Pusat Perbelanjaan Dan Toko Modern Dalam Perspektif Etika Bisnis

Islam

\title{
Analisis Praktik Pengembangan Usaha Minimarket Berdasarkan Peraturan Walikota Palembang Nomor 25 Tahun 2011 Tentang Pedoman Penataan Dan Pembinaan Pusat Perbelanjaan Dan Toko Modern Dalam Perspektif Etika Bisnis Islam
}

\author{
Fety Vera \\ UIN Raden Fatah Palembang) \\ Vetyvera123@gmail.com
}

\begin{abstract}
Abstrak
Persaingan pasar didalam usaha keperluan primer manusia terletak pada bisnis ritel yang juga ikut mengalami persaingan. Bisnis eceran atau ritel adalah semua kegiatan yang terlibat dalam penjualan barang atau jasa secara langsung ke konsumen akhir untuk penggunaan pribadi dan bukan untuk bisnis. Sebagaimana yang kita ketahui bahwa persaingan bisnis merupakan konsekuensi dari pelaku usaha, tidak terkecuali perdagangan ritel yang ada di Indonesia. Masalah yang dibahas disini adalah Peran Pemerintah dalam Penataan Wilayah Usaha Minimarket dan pelanggaran Hukum yang dilakukan oleh pelaku Usaha Minimarket di Kota Palembang. Adapun rumusan masalah meliputi tentang bagaimanakah pengembangan usaha minimarket berdasarkanPeraturan Walikota Palembang Nomor 25 Tahun 2011. Tujuannya yaitu menganalisis pengembangan usaha minimarket berdasarkanPeraturan Walikota Palembang Nomor 25 Tahun 2011 di jalan Kapten Abdullah Kelurahan Plaju Ilir Kecamatan Seberang Ulu II Kota Palembang.
\end{abstract}

Kata Kunci: Persaingan Usaha, Peraturan Pemerintah, Etika Bisnis Islam

\begin{abstract}
The market competition in primary human need business lies in retail businesses that also experience competition. Retail or retail businesses are all activities involved in the sale of goods or services directly to the final consumer for personal and non-business use. As we know that business competition is a consequence of business actors, not excluding retail trade in Indonesia. The issues discussed here are the Government's Role in the Regulation of Minimarket Business Areas and Lawlessness Committed by Minimarket Business actors in Palembang City. The formulation of the problem includes about how the development of minimarket based on the Regulation of the Mayor of Palembang Number 25 years 2011. The aim is to analyze the develpoment of minimarket based on Regulation of the Mayor of Palembang Number 25 years 2011 on the
\end{abstract}

Tersedia Online di http://jurnal.radenfatah.ac.id/index.php/medinate 
Fety Vera

Analisis Praktik Pengembangan Usaha Minimarket Berdasarkan Peraturan Walikota Palembang Nomor 25 Tahun 2011 Tentang Pedoman Penataan Dan Pembinaan Pusat Perbelanjaan Dan Toko Modern Dalam Perspektif Etika Bisnis

Islam

road Kapten Abdullah Kelurahan Plaju Ilir Kecamatan Seberang Ulu II Kota Palembang.

Keywords: business competition, Government Regulation, Islamic Business Ethics

\section{Pendahuluan}

Ekonomi global mulai berkembang pada tahun 2015. Hal tersebut disampaikan dalam beberapa informasi pertemuan ekonomi yang menyatakan bahwa sektor ekonomi menjadi sebuah keniscayaan dalam melaksanakan kehidupan di dunia.Era tersebut juga masuk di ranah perkembangan usaha di Indonesia dimana dari berbagai usaha yang mengalami proses persaingan pasar.

Persaingan pasar didalam usaha keperluan primer manusia terletak pada bisnis ritel yang juga ikut mengalami persaingan. Bisnis eceran atau ritel adalah semua kegiatan ataupun aktivitas yang terlibat dalam penjualan barang atau jasa secara langsung ke konsumen akhir sebagai penggunaan pribadi dan tidak untukbisnis. Sebagaimana kita ketahui bahwa persaingan bisnis merupakan konsekuensi dari pelaku usaha, tidak terkecuali perdagangan ritel yang terjadi di Indonesia. (Philip Kottler, 2005: 215)

Bisnis Ritel yang dahulunya disebut dengan bisnis eceran ini, merupakan bisnis yang menyelamatkan perekonomian banyak orang dan memberi keuntungan sementara bagi orang lain. Pada saat krisis moneter melanda Indonesia diakhir tahun 1997, yang kemudian berkembang menjadi krisis ekonomi, perekonomian Indonesia banyak tertolong dengan bisnis eceran. Dibanyak negara, termasuk negara-negara terkemuka seperti Prancis, Inggris dan AS, bisnis eceran merupakan salah satu keuntungan besar. (Hendri, 2005: 2)

Tumbuh kembangnya minimarket pada satu sisi, menunjukkan perkembangan perekonomian yang bagus. Pertumbuhan minimarket hingga ke daerah-daerah merupakan wujud dari kemajuan perekonomian secara makro. Namun disisi lain, gairah ekonomi itu ternyata memicu keresahan dikalangan pedagang kelontong. Kehadiran ritel modern tersebut telah memunculkan iklim persaingan yang tidak sehat dan cenderung merugikan pedagang kelontong. Tidak menutup kemungkinan kondisi yang timpang tersebut juga berpotensi menimbulkan benih-benih kecemburuan sosial diantara para pelaku usaha. Membuat pedagang kelontong khususnya merupakan pedagang dengan modal yang sangat terbatas, kondisi usaha semakin terpuruk bahkan bisa mati. Pemerintah telah mengupayakan penataan minimarket sebagaimana telah diatur dalam Peraturan Presiden (Perpres) Nomor 112 Tahun 2007 tentang penataan dan pembinaan pasar tradisional, pusat perbelanjaan, serta toko modern. Dan dalam 


\section{Fety Vera \\ Analisis Praktik Pengembangan Usaha Minimarket Berdasarkan Peraturan Walikota Palembang Nomor 25 Tahun 2011 Tentang Pedoman Penataan Dan Pembinaan Pusat Perbelanjaan Dan Toko Modern Dalam Perspektif Etika Bisnis \\ Islam}

Peraturan Daerah Nomor 2 Tahun 2002 tentang perpasaran swasta, telah diatur bahwa jarak antara pasar tradisional dan modern minimal 2,5 kilometer. (RI, Lembaran Daerah Provinsi Daerah Khusus Ibukota Jakarta, Nomor 76, Tahun 2002)

Sebagian besar pengusaha kecil yang diwawancarai tersebut menyatakan berdirinya swalayan indomaret memberikan dampak negatif terhadap usaha mereka, yaitu berupa: penghasilan atau omset penjualan menjadi turun drastis, banyak usaha kecil yang tutup atau tidak berjualan lagi karena kalah bersaing dalam harga dan pelayanan dengan toko swalayan indomaret, biaya kehidupan rumah tangga mereka terancam, karena sebelumnya warung tersebut merupakan mata pencarian untuk membiayai kehidupan sehari-hari. Keberadaan Minimarket tersebut memberikan dampak merugikan pengusaha kecil yang berada disekitarnya, disetiap toko swalayan indomaret. Padahal disekitarnya diperkirakan ada 10 usaha kecil, maka apabila ada 290 toko swalayan indomaret akibatnya 2900 usaha kecil terancam mati, karena kalah bersaing dengan harga dan kenyamanan yang disediakan oleh indomaret. Apabila dibiarkan rencana berdirinya sampai 2000 Toko Swalayan indomaret, maka diperkirakan 20.000 usaha kecil yang berada di Jabotabek akan mati atau minimal 80.000 orang masyarakat miskin tambah melarat, resah kehilangan mata pencarian. (Keputusan Komisi Pengawas Persaingan Usaha Republik Indonesia Nomor: 03/KPPU-L$\mathrm{I} / 2000)$

Dinamika tersebut juga berkembang dalam beberapa kasus sepertipersoalan minimarket, persoalan tentang tata letak wilayah minimarket juga menjadi Problem di mana ada Indomaret, di situ ada pula Alfamart. Sehingga berdampak buruk bagi pedagang kecil yang ada di sekitar minimarket.Kondisi ini terjadi karena tidak adanya kepatuhan dari pihak perusahaan dalam mentaati regulasi dan pedoman yang secara khusus mengatur keberadaan minimarket tersebut, baik dari segi lokasi, jumlah dalam satu wilayah, jarak, dan jangkauan pelayanan. Hingga persoalan ini akan berdampak buruk bagi masyarakat sekitar dan para konsumen yang berbelanja di minimarket, di dalam bisnis ada sebuah etika bisnis yang harus di implementasikan, baik dari segi moralitas maupun norma-norma agama, agar para pelanggan merasa tidak dirugikan. (Bernard E. Silaban Sukardi Arifin, 2012: 2)

Hal yang sama juga terjadi di kota Palembang, tepatnya di Jalan Kapten Abdullah Kelurahan Plaju Ilir Kecamatan Seberang Ulu II Kota Palembang Provinsi Sumatera Selatan. Tepatnya didalam pasar Plaju tersebut terdapat Indomaret, yang jaraknya kurang dari 2,5 meter. Dan dengan jarak yang sama 
Fety Vera

Analisis Praktik Pengembangan Usaha Minimarket Berdasarkan Peraturan Walikota Palembang Nomor 25 Tahun 2011 Tentang Pedoman Penataan Dan Pembinaan Pusat Perbelanjaan Dan Toko Modern Dalam Perspektif Etika Bisnis

Islam

pula terdapat Alfamart, yang disisi kanan dan kirinya terdapat toko kelontong yang telah berdiri sejak lama. Namun sangat disayangkan, toko kelontong yang berada disisi kiri dan kanan minimarket tersebut sepi dari pengunjung. Karena pengunjung lebih tertarik untuk belanja didalam minimarket tersebut.

Jusmaliani, dkk (2008: 6) menyatakan bahwa sistem dagang dalam pandangan Islam merupakan aspek kehidupan yang dikelompokkan ke dalam masalah mu'amalah yakni masalah yang berkenaan dengan hubungan yang bersifat horizontal dalam kehidupan manusia. Sekalipun sifatnya adalah hubungan yang horizontal namun sesuai dengan ajaran Islam, yang mana mempunyai batasan yaitu tetap mengacu kepada AlQur'an dan Hadis. Sedangkan dalam ajaran Islam perniagaan yang paling menguntungkan adalah perniagaan dengan Allah. Jadi, kita dituntut untuk senantiasa taat pada aturanNya. Selain itu, Rasulullah SAW. Sendiri adalah seorang pedagang yang terkenal karena kejujurannya.

\section{Metode Penelitian}

Penelitian ini merupakan jenis penelitian lapangan (FieldResearch). Penelitian lapangan yang datanya diperoleh dari data lapangan. (SuharsimiArikunto, 2010: 10) Seperti metode penelitian lapangan pada umumnya, maka penelitian berkenaan dengan Analisis Praktik Pengembangan Usaha Minimarket Berdasarkan Peraturan Walikota Palembang Nomor 25 Tahun 2011 Tentang Pedoman Penataan Dan Pembinaan Pusat Perbelanjaan Dan Toko Modern Dalam Perspektif Etika Bisnis Islam. Pendekatan yang digunakan dalam melakukan penelitian ini adalah pendekatan filosofi, yaitu suatu penelitian yang diharapkan dapat memberikan efek penerapan suatu aturan. (Ibrahim, 2008: 320-321)

\section{Kerangka Teori}

Dari keterangan diatas, maka akan digunakan tiga kerangka teori untuk membahas persoalan-persoalan tersebut.

Pertama, Grand Teori, tentang keseimbangan ekonomi. Menurut pendapat Sri Edi Swasono dalam bukunya Daulat Rakyat versus Daulat Pasar dinyatakan bahwa pasar adalah suatu mekanisme lelangan belaka, yang kuat (memiliki dana) akan memenangkan lelang. Bagi yang tidak memiliki kekuatan dana akan dikalahkan atau hanya akan menjadi penonton dan berada diluar pagar transaksi ekonomi. (Sri Edi Swasono, 2005: 15; Euis Amalia, 2009: 121) Teori ini digunakan untuk memberikan penjelasan bahwa minimarket yang ada disekitar masyarakat saat ini adalah usaha waralaba yang memonopoli pasar, sehingga dapat menggerus warung-warung kelontong disekitarnya. Ini dikarenakan sumber

Tersedia Online di http://jurnal.radenfatah.ac.id/index.php/medinate 
Fety Vera

Analisis Praktik Pengembangan Usaha Minimarket Berdasarkan Peraturan Walikota Palembang Nomor 25 Tahun 2011 Tentang Pedoman Penataan Dan Pembinaan Pusat Perbelanjaan Dan Toko Modern Dalam Perspektif Etika Bisnis

Islam

modal atau dana yang mereka miliki tentulah jauh lebih besar dari pada modal rakyat yang jauh lebih sedikit. Sehingga pemilik minimarket mampu menyediakan berbagai macam kebutuhan rumah tangga dan fasilitas yang lebih nyaman menurutnya. Alhasil dengan sendirinya warung-warung rakyat pun akan mati dengan sendirinya, dikarenakan para pembeli beralih belanja ke minimarket.

Kedua, Middle Teori, tentang Etika Ekonomi dalam Islam. Dalam agama Islam, aktivitas dan tujuan ekonomi dianggap sebagai suatu kaidah atau cara yang digunakan untuk mencapai kehidupan. Keselarasan dalam ekonomi harus diselaraskan dengan tujuan yang terakhir yaitu untuk mencapai falah. Prinsip ekonomi Islam bertujuan untuk mengembangkan kebajikan semua pihak sebagaimana yang dinyatakan oleh konsep falah yang terdapat dalam Al Qur'an. Prinsip ini menghubungkan prinsip ekonomi dengan nilai moral secara langsung. Untuk mencapai falah, dalam menjalankan aktifitas ekonomi harus mengandung dasar-dasar moral. Begitupun dalam membuat keputusan yang berkaitan dengan ekonomi, nilai etika sepatutnya dijadikan sebagai norma, dan selanjutnya yang berkaitan dengan ekonomi haruslah dianggap sebagai hubungan moral. (Muhammad Nejatullah Siddiqi, 1996: 5)

Yusuf Qardawi, dalam bukunya norma dan etika ekonomi Islam secara tegas telah memisahkan antara nilai-nilai dan perilaku dalam praktik perdagangan. Di antara norma-norma atau nilai-nilai syariah itu adalah sebagai berikut: (Yusuf Qardhawi, 1997: 173)

1. Menegakkan larangan memperdagangkan barang-barang yang diharamkan.

2. Bersikap benar, amanah, dan jujur.

3. Menegakkan keadilan dan mengharamkan bunga.

4. Menerapkan kasih saying dan mengharamkan monopoli.

5. Menegakkan toleransi dan persaudaraan.

6. Berpegang pada prinsip bahwa perdagangan adalah bekal menuju akhirat.

Adapun macam-macam Etika Bisnis dalam konsep Ekonomi Islam terdapat dua macam etika, yaitu: (Johan Arifin, 2009: 13)

1. Etika Deskriptif

Adalah etika yang menelaah secara kritis dan rasional tentang sikap dan perilaku manusia, secara apa yang dikejar setiap orang dalam hidupnya sebagai sesuatu yang bernilai. Artinya etika deskriptif tersebut berbicara mengenai fakta secara apa adanya, yakni mengenai nilai dan perilaku manusia sebagai suatu fakta yang berhubungan dengan situasi dan

Tersedia Online di http://jurnal.radenfatah.ac.id/index.php/medinate 
Fety Vera

Analisis Praktik Pengembangan Usaha Minimarket Berdasarkan Peraturan Walikota Palembang Nomor 25 Tahun 2011 Tentang Pedoman Penataan Dan Pembinaan Pusat Perbelanjaan Dan Toko Modern Dalam Perspektif Etika Bisnis

Islam

realitas yang membudaya. Dapat disimpulkan bahwa tentang kenyataan dalam penghayatan nilai atau tanpa nilai dalam suatu golongan masyarakat yang dihubungkan dengan kondisi tertentu memungkinkan manusia dapat bertindak dan berlaku secara etis.

\section{Etika Normatif}

Etika yang menetapkan berbagai sikap dan perilaku yang ideal dan seharusnya dimiliki oleh manusia atau apa yang seharusnya dijalankan oleh manusia dan tindakan apa yang bernilai dalam hidup ini. Jadi etika normative merupakan norma-norma yang dapat menuntun agar manusia bertindak secara baik dan menghindarkan hal-hal yang buruk, sesuai dengan kaidah atau norma yang disepakati dan berlaku dimasyarakat.

Ketiga, Applied Teori, tentang Persaingan Usaha. Persaingan usaha bisnis adalah istilah yang sering muncul dalam berbagai literatur yang menuliskan perihal aspek hokum persaingan bisnis. Persaingan adalah organisasi atau perorangan berlomba untuk mencapai tujuan yang diinginkan seperti konsumen, pangsa pasar, peringkat survey, atau sumberdaya yang dibutuhkan. (Mujradad Kuncoro, 2005: 86)

Lahirnya Undang-Undang Nomor 5 Tahun 1999 tentang Larangan Praktik Monopoli dan Persaingan Usaha Tidak Sehat (UU 5/1999) bertindak aktif dalam mengawasi berbagai tindakan perilaku pelaku usaha yang dapat merugikan maupun memberikan dampak yang luas bagi kesehatan persaingan bagi para pelaku usaha di Wilayah Hukum Indonesia.

Sebagai bahan perbandingan, di Ibukota Negara yang dengan kepadatan penduduk semakin meningkat dan pembangunan semakin bertambah dari waktu ke waktu, tetapi pemerintah tetap memperhatikan dan mengatur keberadaan minimarket sebagaimana telah diatur dalam Peraturan Daerah Propinsi Daerah Khusus Ibukota Jakarta Nomor 2 Tahun 2002 tentang Perpasaran Swasta di Propinsi Daerah Khusus Ibukota Jakarta. Disebutkan dalam Pasal 10 Peraturan Daerah Propinsi Daerah Khusus Ibukota Jakarta Nomor 2 Tahun 2002 tentang Perpasaran Swasta di Propinsi Daerah Khusus Ibukota Jakarta, dalam menyelenggarakan usaha perpasaran swasta, jarak sarana/ tempat usaha harus memenuhi persyaratan sebagai berikut:

Tersedia Online di http://jurnal.radenfatah.ac.id/index.php/medinate 
Fety Vera

Analisis Praktik Pengembangan Usaha Minimarket Berdasarkan Peraturan Walikota Palembang Nomor 25 Tahun 2011 Tentang Pedoman Penataan Dan Pembinaan Pusat Perbelanjaan Dan Toko Modern Dalam Perspektif Etika Bisnis

Islam

a. Usaha perpasaran swasta yang luas lantainya $100 \mathrm{~m}^{2}$ sampai dengan $200 \mathrm{~m}^{2}$ harus berjarak radius $0,5 \mathrm{~km}$ dari pasar lingkungan dan terletak disisi jalan Lingkungan/ Kolektor/ Arteri;

b. Usaha perpasaran swasta yang luas lantainya di atas $200 \mathrm{~m}^{2}$ sampai dengan $1.000 \mathrm{~m}^{2}$ harus berjarak radius $1,0 \mathrm{~km}$ dari pasar lingkungan dan terletak disisi jalan Lingkungan/ Kolektor/ Arteri;

c. Usaha perpasaran swasta yang luas lantainya di atas $1.000 \mathrm{~m}^{2}$ sampai dengan $2.000 \mathrm{~m}^{2}$ harus berjarak radius $1,5 \mathrm{~km}$ dari pasar lingkungan dan terletak disisi jalan Lingkungan/ Kolektor/ Arteri;

d. Usaha perpasaran swasta yang luas lantainya di atas $2.000 \mathrm{~m}^{2}$ sampai dengan $4.000 \mathrm{~m}^{2}$ harus berjarak radius $2 \mathrm{~km}$ dari pasar lingkungan dan terletak disisi jalan Lingkungan/ Kolektor/ Arteri;

e. Usaha perpasaran swasta yang luas lantainya di atas $4.000 \mathrm{~m}^{2}$ harus berjarak radius 2,5 km dari pasar lingkungan dan terletak disisi jalan Lingkungan/ Kolektor/ Arteri; (Lembaran daerah Provinsi Daerah Khusus Ibukota Jakarta, Nomor 76, Tahun 2002)

Dengan adanya aturan tersebut, maka para pelaku usaha kelompok (waralaba) maupun pelaku usaha individu (warung kecil) akan bersaing secara sehat dan tidak saling merugikan.

Strategi persaingan bisnis dalam pandangan syariah dibolehkan dengan kriteria persaingan secara baik. Salah satunya dijelaskan dalam AlQur'an Surat Al-Baqarah ayat 148 yang Artinya:

"Dan bagi tiap-tiap umat ada kiblatnya (sendiri) yang ia menghadap kepadanya. Maka berlomba-lombalah (dalam membuat) kebaikan. Dimana saja kamu berada pasti Allah akan mengumpulkan kamu sekalian (pada hari kiamat). Sesungguhnya Allah Maha Kuasa atas segala sesuatu”.

Dalam kandungan ayat Al-Qur'an diatas dijelaskan bahwa persaingan untuktujuan kebaikan itu diperbolehkan, selama persaingan itu tidak melanggar prinsip syariah. Seperti dicontohkan oleh Rasulullah, ketika berdagang Rasul tidak pernah melakukan usaha yang membuat usaha 


\begin{abstract}
Fety Vera
Analisis Praktik Pengembangan Usaha Minimarket Berdasarkan Peraturan Walikota Palembang Nomor 25 Tahun 2011 Tentang Pedoman Penataan Dan Pembinaan Pusat Perbelanjaan Dan Toko Modern Dalam Perspektif Etika Bisnis

Islam

persaingan hancur, walaupun tidak berarti gaya berdagang Rasul seadanya tanpa memperhatikan daya saingnya. Yang Beliau lakukan adalah memberikan pelayanan yang sebaik-baiknya dan menyebutkan spesifikasi barang yang dijual dengan jujur, termasuk jika ada kecacatan pada barangnya". (M. Ismail Yusantodan M. Karebat Widjajakusuma, 2002: 96)
\end{abstract}

\title{
Hasil Penelitian
}

Berdasarkan hasil penelitian dapat diketahui bahwa Pemerintah sebagai salah satu pelaku ekonomi (rumah tangga pemerintah), memiliki peran penting dalam perekonomian yaitu fungsi sebagai alokasi, distribusi dan stabilisasi (Suparmoko, 2000):

1. Fungsi alokasi, yakni fungsi pemerintah sebagai penyedia barang dan jasa publik seperti pembangunan jalan raya, gedung sekolah, penyedia fasilitas penerangan, dan telepon.

2. Fungsi Disribusi, yakni fungsi pemerintah dalam pemerataan dan distribusi pendapatan masyarakat.

3. Fungsi Stabilisasi, yakni fungsi pemerintah dalam menciptakan kestabilan ekonomi, sosial politik, hukum, pertahanan dan keamanan.

Peran pemerintah menjadi lebih penting karena mekanisme pasar saja tidak mampu menyelesaikan semua persoalan dalam praktik ekonomi. Untuk menjamin efisiensi, pemerataan dan stabilitas ekonomi, peran dan fungsi negara mutlak diperlukan dalam perekonomian sebagai pengendali mekanisme pasar. Walaupun dalam sistem ekonomi pasar, masalah ekonomi utama diserahkan kepada mekanisme pasar, namun ada beberapa kasus tertentu pemerintah tetap harus melakukan campur tangan untuk menghindari kekacauan dalam bidang ekonomi (Azis, 2008:115).

Pada dasarnya, pemerintah ikut serta dalam kegiatan perekonomian untuk menanggulangi kegagalan pasar sehingga tidak adanya pihak-pihak yang dirugikan. Adapun bentuk campur tangan yang dilakukan pemerintah dalam kegiatan ekonomi dapat dibedakan dalam tiga bentuk (Sukirno, 2013:412):

1. Membuat dan melaksanakan peraturan dan Undang-undang.

Tujuan pokok dari peraturan yang dibuat oleh pemerintah adalah agar kegiatan-kegiatan ekonomi dijalankan secara wajar dan tidak merugikan khalayak ramai, dan peraturan tersebut meliputi pengaturan terhadap berbagai aspek dari kegiatan ekonomi. Baik mengatur kegiatan dan pendirian industri tetapi juga kegiatan ekspor dan impor, perbaikan lalu lintas, pengembangan perusahaan dan berbagai aspek ekonomi lainnya (sukirno, 2013:45). 


\section{Fety Vera}

Analisis Praktik Pengembangan Usaha Minimarket Berdasarkan Peraturan Walikota Palembang Nomor 25 Tahun 2011 Tentang Pedoman Penataan Dan Pembinaan Pusat Perbelanjaan Dan Toko Modern Dalam Perspektif Etika Bisnis

Islam

2. Secara langsung melakukan beberapa kegiatan ekonomi (membuat perusahaan).

Dalam beberapa kegiatan-kegiatan tertentu undang-undang saja belum dapat memberi jaminan bahwa kegiatan-kegiatan itu dapat dilaksanakan secara efisien, atau akan memberi kemakmuran yang paling tinggi kepada masyarakat. Bahkan adakalanya masyarakat akan mendapat keuntungan yang sangat besar apabila kegiatan-kegiatan tersebut diserahkan kepada pihak pemerintah. Untuk kegiatan-kegiatan yang mempunyai sifat seperti itu pemerintah akan melakukan campur tangan secara langsung, yaitu pemerintah akan langsung turut serta melakukan kegiatan-kegiatan memproduksi barang tersebut (Sukirno, 2013:415).

Salah satu tujuannya adalah untuk menjamin supaya barang atau jasa itu dapat disediakan kepada masyarakat dengan harga yang murah, tetapi tanpa mengurangi efisiensi pelayanannya. Contoh: pemerintah menjalankan sendiri perusahaan pengangkutan kereta api, dengan tujuan untuk menjamin agar pengangkutan kereta api dapat disediakan dengan efisien dan murah.

3. Melakukan kebijakan fiskal dan moneter.

Kebijakan moneter adalah kebijakan yang dilakukan oleh bank sentral untuk mengatur jumlah uang dalam perekonomian. Kebijakan fiskal adalah kebijakan pemerintah dalam memungut pajak dan membelanjakan pendapatan pajak tersebut untuk membiayai kegiatan-kegiatannya.

Sesungguhnya aturan yang digunakan oleh pemerintah sudah sangat tepat untuk membatasi pergerakan bisnis waralaba yang menyimpang dan mengancam kelangsungan bisnis toko kelontong dan pedagang kaki lima disekitarnya. Namun masih banyak pelanggaran-pelanggaran dalam pelaksanaan aturan pemerintah tersebut. Untuk itu, penggunaan Peraturan Walikota Nomor 25 Tahun 2011 Tentang Pedoman Penataan dan Pembinaan Pusat Perbelanjaan dan Toko Modern perlu diperketat aturan demi aturan.

Perijinan waralaba minimarket perlu diperketat mengingat banyaknya praktek pelanggaran yang dilakukan pihak-pihak tersebut. Pembangunan minimarket baru perlu diawasi oleh pihak pemerintah dengan melibatkan persetujuan dari warga sekitar dalam hal tersebut.

Franchise minimarket didirikan oleh para penyedia modal yang lebih besar daripada pedagang kecil. Pendirian franchise minimarket yang semakin pesat dan kehadirannya diharapkan oleh masyarakat setempat sebagai sarana berbelanja. Toko dengan konsep modern didirikan oleh pemilik modal besar tentu sangat berpengaruh terhadap politik penguasaan perdagangan dibidang ekonomi. Pemilik 
Fety Vera

Analisis Praktik Pengembangan Usaha Minimarket Berdasarkan Peraturan Walikota Palembang Nomor 25 Tahun 2011 Tentang Pedoman Penataan Dan Pembinaan Pusat Perbelanjaan Dan Toko Modern Dalam Perspektif Etika Bisnis

Islam

pedagang kecil harus bersinergi dalam membangun usahanya sebagai "penyedia barang dan jasa distribusi sembako, jika merasa kurang lengkap hendaknya berupaya untuk meminta bantuan kepada pemerintah setempat agar memajukan usaha pribumi berupa pinjaman koperasi. Penyediaan dari pedagang kecil yang modalnya dibantu oleh pemerintah niscaya akan memudahkan masyarakat dalam memenuhi kebutuhannya secara lengkap, contoh penyediaan macam-macam susu bayi terkadang sangat jarang terpenuhi lengkap pilihan-pilihan menurut usia bayi/balita. Bantuan dari pemerintah setempat kepada para pedagang kecil akan memberikan kesempatan baginya untuk lebih berkembang. Selain dari bantuan materi, Pedagang kecil juga membutuh bantuan dalam bentuk perlindungan hukum yang dapat menjamin padagang kecil mampu bertahan dengan hadirnya franchise minimarket disekitarnya. Para pedadang kecil bukan suatu badan usaha yang mampu memiliki legalitas perusahaan seperti franchise minimarket Alfamart dan Indomaret, namun kebutuhan masyarakat pada pedagang kecil dalam bentuk toko dan warung kecil masih banyak diharapkan berdiri sebagai perpanjangan tangan para produsen. Masyarakat juga masih banyak yang mengandalkan pencarian sebagai pedagang kecil meskipun sebagian besar tiddak memiliki legalitas pendirian. (Rissa Afni Martinouva, 2017: 88-89)

Pihak pemerintah seharusnya juga bisa mencegah terjadinya pelanggaran dengan memberikan peringatan dan himbauan kepada pemilik usaha waralaba minimarket mengenai aturan dalam pendirian usaha minimarket tersebut. Dengan demikian dapat diharapkan terjadinya pelanggaran atas pendirian minimarket dapat berkurang sehingga kelangsungan bisnis toko kelontong dan pedagang kaki lima disekitarnya tidak terganggu.

Dalam pasal 3 ayat 9 ,

Pendirian minimarket baik yang berdiri sendiri maupun yang terintegrasi dengan pusat perbelanjaan atau bangunan lain wajib memperhatikan:

a. Kepadatan penduduk;

b. Perkembangan pemukiman baru;

c. Aksesibilitas wilayah (arus lalu lintas) dan ketersediaan lahan parkir

d. Dukungan atau ketersediaan infrastruktur; dan

e. Keberadaan pasar tardisional dan warung/ toko di wilayah sekitar yang lebih kecil dari pada minimarket tersebut.

Dari poin-poin diatas, maka kita tau bahwa dalam mendirikan minimarket wajib memperhatikan hal-hal tersebut dan tidak melanggar aturan yang telah dibuat, sehingga tercipta persaingan yang sehat dan tidak merugikan pihak manapun. Tetapi kenyataannya praktek yang terjadi dilapangan tidak demikian, dikarenakan masih banyak minimarket yang tidak memperhatikan keberadaan

Tersedia Online di http://jurnal.radenfatah.ac.id/index.php/medinate 


\section{Fety Vera}

Analisis Praktik Pengembangan Usaha Minimarket Berdasarkan Peraturan Walikota Palembang Nomor 25 Tahun 2011 Tentang Pedoman Penataan Dan Pembinaan Pusat Perbelanjaan Dan Toko Modern Dalam Perspektif Etika Bisnis

Islam

pasar tradisional dan warung-warung kecil disekitarnya, sebagaimana disebutkan dalam poin (e).

Hal ini tanpa disadari kita bersama, lama kelamaan akan menggerus warung-warung kecil disekitarnya. Tanpa mempertimbangkan lebih lanjut, masyarakat dengan sendirinya akan beralih untuk berbelanja ke minimarket yang baru, dengan iming-iming diskon (potongan harga), barang-barang promosi, bonus, hadiah menarik, belum lagi ditambah dengan kenyamanan tempat dan variasi produk atau barang yang dijual.

Inilah yang akan terjadi seterusnya jika pemerintah tidak langsung turun ke lapangan, melihat bagaimana dampak yang akan terjadi jika semakin banyak minimarket yang berkembang dari waktu ke waktu. Warung-warung kecil yang telah berdiri puluhan tahun sebelumnya terpaksa ditutup karena tidak dapat mengembalikan modal, semakin hari semakin sepi pembeli yang mampir ke warung kecilnya.

Kondisi pedagang eceran tradisional (warung/toko tradisional) di Sumatera Selatan bakal makin terjepit dengan maraknya pendirian toko modern sejenis minimarket yang merengsek sampai pelosok kecamatan melalui sistem waralaba. Tentu saja pedagang tradisional tidak akan mampu bersaing baik dalam pelayanan mau pun harga jual bila dibandingkan dengan minimarket waralaba. (http://musiinstitute.wordpress.com/2012/01/11/butuh-regulasi-atur-minimarketdi-sumsel/ akses tanggal 14 Desember 2017, pukul 09.54 WIB)

Sebagaimana kita ketahui bahwa langkah pemerintah dalam mengeluarkan kebijakan dalam bentuk Peraturan Walikota Palembang Nomor 25 Tahun 2011 telah sesuai dengan apa yang diharapkan oleh masyarakat dan pedagang kecil khususnya, akan tetapi langkah ini belum usai, karena masih banyak praktek dilapangan yang belum/ tidak sesuai dengan peraturan yang telah ditetapkan tersebut.

Selanjutnya, untuk memberikan keseimbangan pertumbuhan pada sektor perdagangan eceran secara keseluruhan maka perlu dilakukan penataan dalam setiap pendirian minimarket. Selain itu perlu dilakukan pembinaan terhadap para pedagang tradisional agar mampu mengikuti perkembangan zaman dengan berubahnya orientasi dan pola berbelanja masyarakat.

Sejalan dengan berkembangnya pertumbuhan ekonomi di kota Palembang, membuka peluang usaha minimarket dan waralaba untuk mendirikan lebih banyak lagi usaha-usahanya. Hal inilah yang menjadi bahasan dalam pedoman penataan wilayah minimarket yang tidak lagi sejalan dan memperhatikan peraturan yang telah ditetapkan oleh pemerintah kota Palembang. 
Fety Vera

Analisis Praktik Pengembangan Usaha Minimarket Berdasarkan Peraturan Walikota Palembang Nomor 25 Tahun 2011 Tentang Pedoman Penataan Dan Pembinaan Pusat Perbelanjaan Dan Toko Modern Dalam Perspektif Etika Bisnis

Islam

Dalam kajian etika bisnis Islam, Menurut Johan Arifin (2009:22), etika bisnis adalah seperangkat nilai tentang baik, buruk, benar, dan salah dalam dunia bisnis berdasarkan pada prinsip-prinsip moralitas. Dalam arti lain etika bisnis juga bisa dikatakan sebagai seperangkat prinsip dan norma dimana para pelaku bisnis harus mempunyai komitmen dalam melakukan sebuah transaksi, berperilaku, dan juga berelasi guna mencapai tujuan bisnisnya dengan selamat. Dengan demikian maka sangat perlu sekali untuk memahami pentingnya kegunaan etika dalam berbisnis. Hal itu dimaksudkan agar seseorang terutama pelaku bisnis mempunyai bekal untuk berbuat the right thing yang dilandasi dengan semangat keilmuan, kesadaran, serta kondisi yang berlandaskan pada nilai-nilai moralitas.

Pada dasarnya peranan pemerintah dalam perekonomian yang Islami, memiliki dasar rasionalitas yang kokoh. Dalam pandangan Islam, peran pemerintah didasari oleh beberapa argumentasi (UP3EI,2009:446):

1. Derivasi dari konsep kekhalifahan

Pemerintah adalah pemegang amanah Allah SWT yang menjalankan tugas-tugas kolektif dalam mewujudkan kesejahteraan dan keadilan serta tata kehidupan yang baik bagi seluruh umat. Peran pemerintah memiliki landasan yang kokoh dalam Al-Qur' an dan as-Sunnah.

2. Konsekuensi adanya kewajiban-kewajiban kolektif

Merupakan suatu kewajiban yang ditujukan kepada masyarakat, dimana jika kewajiban tersebut dilanggar maka seluruh masyarakat akan menanggung dosa, sementara jika telah dilaksanakan maka seluruh masyarakat akan terbebas dari kewajiban tersebut.

3. Adanya kegagalan pasar dalam merealisasikan falah

Kegagalan pasar juga merupakan latar belakang perlunya pemerintah untuk berperan dalam perekonomian. Contoh: persaingan akan memberikan ruang kepada pelaku yang kuat untuk semakin mendominasi pasar, dan mendorong keluar pelaku yang lemah. Jika ini terjadi maka diantaranya akan terjadi monopoli, dan ini tentu saja akan banyak merugikan masyarakat (UP3EI, 2009:448).

Dalam hal penataan wilayah usaha minimarket di kota Palembang, ada beberapa titik daerah dimana pendirian usaha minimarket tidak memperhatikan peraturan pemerintah yang telah ditetapkan dan etika dalam bisnis Islam. Salah satu minimarket yang penulis datangi yaitu minimarket (Indomaret) di jalan Kapten Abdullah Kelurahan Plaju Ilir Kecamatan Seberang Ulu II Kota Palembang, dimana minimarket tersebut kurang dari 2,5 km dari pasar tradisional yang ada, tidak jauh dari minimarket tersebut berdiri minimarket (Alfamart) yang hanya berjarak kurang dari $20 \mathrm{~m}$. Sehingga ada beberapa warung kaki lima yang

Tersedia Online di http://jurnal.radenfatah.ac.id/index.php/medinate 


\section{Fety Vera \\ Analisis Praktik Pengembangan Usaha Minimarket Berdasarkan Peraturan Walikota Palembang Nomor 25 Tahun 2011 Tentang Pedoman Penataan Dan Pembinaan Pusat Perbelanjaan Dan Toko Modern Dalam Perspektif Etika Bisnis}

Islam

disisi kiri dan kanannya bahkan hanya berseberangan jalan saja berdiri minimarket modern, yang hadir dengan berbagai penawaran menarik untuk mengalihkan masyarakat agar berbelanja di minimarket tersebut.

Dapat dibayangkan akan bertahan berapa lama warung-warung kecil tersebut berdiri, dengan modal seadanya dan pendapatan sehari-hari yang sangat tipis. Sehingga barang-barang dagangan pun akan dikonsumsi sendiri, karena tidak mampu bersaing dengan minimarket modern yang berada disampingnya.

Ketika dipahami sebagai seperangkat prinsip moral yang membedakan apa yang benar dari apa yang salah maka etika diperlukan dalam bisnis, sebagaimana diketahui, bahwa bisnis adalah suatu serangkaian peristiwa yang melihatkan pelaku bisnis. Para pelaku bisnis memiliki kecendrungan untuk melakukan tabrakan kepentingan, saling menghalalkan cara, dalam rangka memperoleh keuntungan sebanyak mungkin, sementara yang lemah terperosok di sudut-sudut ruang bisnis. Jadi etika bisnis adalah refleksi kritis dan rasional dari prilaku bisnis dengan memperhatikan moralitas dan norma untuk mencapai tujuan. Oleh karena itu etika sangat berpengaruh terhadap para pelaku bisnis terutama dalam hal kepribadian, tindakan dan prilakunya, jika seseorang pengusaha dapat membentuk karakter dirinya sendiri sesuai dengan akhlak yang mulia, maka akan berhasil mencapai keuntungan dalam hidup ini dandalam kehidupan yang akan datang. Dalam etika pembentukan karakter mencakup nilai moral, prilaku dan melakukan pada kegiatan yang dilakukan oleh seseorang pengusaha dari sudut pandang yang di perbolehkan maupun yang dilarang.

Pada dasarnya sumberdaya apapun yang ada di bumi dan di langit adalah karunia Allah SWT yang seharusnya manusia, selama tidak ada larangan seperti ditegaskan dalam kaidah diatas. Artinya kebolehan dan kebebasan berkreasi dalam bidang ekonomi haruslah dalam koridor yang dibolehkan al-Qur'an dan Hadis. Kaidah ini memberi keseimbangan antara bebas berkreasi, berinovasi, bertransaksi, tapi ada batasnya, selama tidak bertentangan dengan syar'i.

\section{Penutup}

Berdasarkan pembahasan yang telah diuraikan diatas, maka dapat diambil kesimpulan sebagai berikut: Pengembangan usaha minimarket yang bertentangan denganPeraturan Walikota Palembang Nomor 25 Tahun 2011, Dalam mendirikan minimarket wajib memperhatikan aturan-aturan dan tidak melanggar aturan yang telah dibuat, sehingga tercipta persaingan yang sehat dan" tidak merugikan pihak manapun. Tetapi kenyataannya praktek yang terjadi dilapangan tidak demikian, dikarenakan masih banyak minimarket yang tidak "memperhatikan keberadaan pasar tradisional dan warung-warung kecil disekitarnya. Pengembangan usaha 
Fety Vera

Analisis Praktik Pengembangan Usaha Minimarket Berdasarkan Peraturan Walikota Palembang Nomor 25 Tahun 2011 Tentang Pedoman Penataan Dan Pembinaan Pusat Perbelanjaan Dan Toko Modern Dalam Perspektif Etika Bisnis

Islam

minimarket di kota Palembang telah melanggar peraturan yang telah ditetapkan oleh Walikota Palembang, yang mana salah satu minimarket di Jalan Kapten Abdullah Kelurahan Plaju Ilir Kecamatan Seberang Ulu II Kota Palembang Provinsi Sumatera Selatan, telah mendirikan minimarket yang letaknya sangat berdekatan dengan pasar tradisional dan warung kelontong, bangunan minimarket ini juga saling berhadapan dengan minimarket lainnya, yang hanya dipisahkan oleh jalan.

Pengembangan usaha minimarket di kota Palembang belum sejalan dengan etika bisnis Islam, dikarenakan para pelaku usaha minimarket masih berdasarkan keinginan masing-masing pemilik usaha Minimarket dalam mencapai tujuan meraup untung sebanyak-banyaknya tanpa memperhatikan warung-warung kecil yang berada disekitarnya. Padahal, dalam Islam diajarkan untuk mengutamakan etika dalam melakukan aktivitas kehidupan sehari-"hari. Dengan demikian maka sangat perlu sekali untuk memahami pentingnya kegunaan etika dalam berbisnis. Hal itu dimaksudkan agar seseorang terutama pelaku bisnis mempunyai bekal untuk berbuat the right thing yang dilandasi dengan semangat keilmuan, kesadaran, serta kondisi yang berlandaskan pada nilai-nilai moralitas.

\section{Daftar Pustaka}

Al-Qur'an

Abdullah, Boedi dan Saebani, Beni Ahmad, Metode Penelitian Ekonomi Islam Muamalah, Bandung: Pustaka Setia, 2014.

Arifin, Johan., Etika Bisnis Islami, Semarang: Walisongo Press, 2009.

Arikunto, Suharsimi.,prosedur Penelitian; suatu pendekatan Praktik . Jakarta: Rineka Cipta. 2010.

Azis, Abdul., Etika Bisnis Perspektif Islam, Bandung: Alfabeta, 2013.

Hadi, Sutrisno.,Metode Research Jilid I dan II. Yogyakarta: Andi Offset. 1987.

Ibrahim ., Metodologi Penelitian Kualitatif.Bandung: Alfabeta, 2008.

Jusmaliani, dkk., Bisnis Berbasis Syariah, Jakarta : Bumi Aksara, 2008

Kottler, Philips., Manajemen Pemasaran, Alih Bahasa Sarwiji, Jakarta: PT. Tema Baru, 2005.

Tersedia Online di http://jurnal.radenfatah.ac.id/index.php/medinate 
Fety Vera

Analisis Praktik Pengembangan Usaha Minimarket Berdasarkan Peraturan Walikota Palembang Nomor 25 Tahun 2011 Tentang Pedoman Penataan Dan Pembinaan Pusat Perbelanjaan Dan Toko Modern Dalam Perspektif Etika Bisnis

Islam

Kuncoro, Mujradad, Strategi Bagaimana Meraih Keunggulan Kompetitif, Jakarta: Erlangga, 2005

Martinouva, Rissa Afni., Perlindungan Hukum Pedagang Kecil Dari Keberadaan Franchise Minimarket (Studi Peraturan Walikota Bandar Lampung Nomor 17 Tahun 2009), Jurnal Keadilan Progresif Vol. 8 No. 1, Bandar Lampung: Universitas Bandar Lampung, 2017.

Moloeng J. Lexy., Metode Penelitian Kualitatif. Bandung: Rosda .2004

Nasution,S.,Metode Penelitian Naturalistik Kualitatif, Bandung:Tarsito.2003.

Patton, Michael Quinn, Metode Evaluasi Kualitatif, (Bandung: Remaja Rosdakarya, 1987.

P3EI., Ekonomi Islam, Jakarta: Rajawali Press, 2009.

Siddiqi, Muhammad Nejatullah., Kegiatan Ekonomi Dalam Islam, Jakarta : Bumi Aksara, 1996.

Sukirno., Makro EkonomiTeori Pengantar, Jakarta: Raja Grafindo Persada, 2013.

Suparmoko., Pengantar Ekonomi Makro, Yogyakarta: UIN Sunan Kalijaga, 2000.

Swasono, Sri Edi, Menegakkan Ideologi Pancasila: Daulat Rakyat Versus Daulat Pasar, Yogyakarta: PUTEP-UGM, 2005

Qardhawi, Yusuf.,Norma dan Etika Ekonomi Islam, Jakarta : Gema Insani Press, 1997.

https://Marketing.co.id, di akses tanggal 30 Maret 2017, Pukul 21.09 WIB

http://musiinstitute.wordpress.com/2012/01/11/butuh-regulasi-atur-minimarket-disumsel/ di akses tanggal14 Desenber 2017, pukul 09.54 WIB

Tersedia Online di http://jurnal.radenfatah.ac.id/index.php/medinate 